\title{
Manipulation of solvent-extractable fat content of milk powders
}

\author{
Phil T. ClARKE*, Mary Ann AUGUSTIN \\ Food Science Australia, Werribee Laboratory, Private Bag 16, Werribee, Victoria 3030, Australia
}

Published online 24 June 2005

\begin{abstract}
A high solvent-extractable fat (SEF) content is a desirable attribute for full-cream milk powder intended for chocolate manufacture. The effects of alteration of process variables on SEF in full-cream milk powders ( $300 \mathrm{~g}$ total fat $\cdot \mathrm{kg}^{-1}$ powder) were examined. Full-cream milk powders produced by conventional powder manufacturing processes have low SEF contents $(<40 \mathrm{~g}$ free fat $\cdot \mathrm{kg}^{-1}$ total fat in powder). Full-cream milk powders with high levels of SEF (up to approximately $400 \mathrm{~g} \cdot \mathrm{kg}^{-1}$ total fat in powder) could be obtained by separating full-cream milk into cream and skim milk fractions, pasteurizing the cream fraction, then, either cooling the cream and recombining it with a skim milk concentrate or homogenizing it at high temperature and pressure prior to combining with a skim milk concentrate. Full-cream milk concentrates produced by either process were then spray dried without homogenization. In addition to the use of altered processing steps for manufacture of milk powders, the level of SEF in milk powder was also influenced by the total solids of the cream and the milk concentrates used in the production of the milk powders.
\end{abstract}

milk powder / solvent extractable fat / spray drying

Résumé - Manipulation du contenu en matières grasses extractibles par solvant des poudres de lait. Un contenu élevé en matières grasses extractibles par solvant (SEF) est une propriété recherchée pour la poudre de lait entier destinée à la fabrication du chocolat. On a étudié les effets de la modification des variables de traitement sur les teneurs en SEF dans des poudres de lait entier contenant $300 \mathrm{~g}$ de matières grasses totales par $\mathrm{kg}$ de poudre. Les poudres de lait entier obtenues par les techniques conventionnelles de fabrication ont de faibles teneurs en $\mathrm{SEF}(<40 \mathrm{~g}$ de matières grasses libres par rapport au total des matières grasses par $\mathrm{kg}$ de poudre). Des poudres de lait entier avec des niveaux élevés en SEF (jusqu'à environ $400 \mathrm{~g}$ par kg de matières grasses contenues dans la poudre) ont pu être obtenues par séparation du lait entier en deux parties, la crème et le lait écrémé, puis pasteurisation de la crème suivie soit d'un refroidissement et de la recombinaison avec le lait écrémé concentré, soit d'une homogénéisation à température et pression élevées avant recombinaison avec le lait écrémé concentré. Les concentrés de lait entier obtenus par ces procédés étaient alors déshydratés par pulvérisation sans homogénéisation. Par ailleurs, la teneur en SEF dans le lait en poudre était également influencée par la teneur en matière sèche de la crème et des concentrés utilisés dans la production des poudres de lait.

poudre de lait / matière grasse libre / séchage par atomisation

\footnotetext{
* Corresponding author: Phil.clarke@ foodscience.afisc.csiro.au
} 


\section{INTRODUCTION}

A high amount of solvent extractable fat (SEF) in full-cream milk powder (FCMP) is a desirable attribute of milk powder ingredients used in chocolate manufacture, although in most other applications a low level of SEF is demanded. Traditional processes for the production of spray-dried milk powders have been developed to decrease the amount of SEF in powders. The commonly used process of full-cream milk powder manufacture involving preheat treatment of milk, concentration, homogenization and drying results in powders with low SEF content, usually less than $30 \mathrm{~g} \cdot \mathrm{kg}^{-1}$ of total fat in a FCMP with a typical fat content of $\sim 260 \mathrm{~g} \cdot \mathrm{kg}^{-1}$. This contrasts with the high amount of SEF $\left(\sim 850 \mathrm{~g} \cdot \mathrm{kg}^{-1}\right.$ of total fat) present in roller-dried milk powder. Rollerdried powder is considered to have superior functionality compared to spray-dried milk powder in chocolate manufacture. A higher SEF content in milk powder is considered desirable for chocolate manufacture as it reduces the amount of cocoa butter and surfactants required to obtain chocolate of desired texture and lessens the energy requirements for chocolate manufacture [16]. Hence, there has been attention paid to the development of spray-dried milk powders with higher level of SEF. However, it should be recognized that a high SEF content is only one of a number of desirable attributes of powders intended for chocolate manufacture. Other factors such as the morphology of the milk powder and the size distribution of the powder particles also influence the functionality of the powder in chocolate $[2,20]$.

Many studies have examined the factors affecting SEF in milk powder. Buma [7] considers that the physical structure of the powder has a significant influence on SEF and that processing steps prior to atomization, except for homogenization, have little effect. Small powder particles have higher level of SEF than large particles and SEF content is also correlated to powder porosity $[5,6]$. Powders produced by nozzle atomization typically have less SEF than those produced by rotary atomization [14]. SEF decreases when the inlet temperature of the spray drier is increased, the outlet temperature is decreased, when the total solid content of the concentrate is increased or its temperature when fed into the drier is decreased $[8,9]$.

SEF content in milk powders is also related to the degree of lactose crystallization in the powder. From the early work of Tamsma et al. [18] it is known that ageing or increasing the lactose crystallization of the milk concentrate results in foam dried powders with 100-900 g. $\mathrm{kg}^{-1}$ SEF. Bohren et al. [4] suggests that 200-900 g. kg-1 SEF in powder can be obtained by seeding the milk concentrate with lactose during powder processing. Others have shown that postdrying lactose crystallization of milk powders by subjecting powders to high relative humidity increases SEF [1].

Both the composition of the milk and the heat treatment of the milk [10] affect SEF in powder. Twomey et al. [19] demonstrated that SEF and particle size of high-fat milk powders were related to the protein content and solid-fat content of the milk and were not affected by the lactose content. Higher SEF content is also obtained with increasing levels of fat in milk powder [13].

In conventional FCMP manufacture, milk is usually preheated, concentrated, homogenized and dried. An alternative commercial process is to combine cream and skim concentrate and homogenize the combined full-cream concentrate prior to drying. These conventional processes result in milk powder with low levels of SEF. In this work, alternative methods of preparation of fullcream milk concentrate were examined. This involved combining pasteurized, cooled cream or homogenized cream of different compositions with skim milk concentrate prior to spray drying the combined full-cream milk concentrate without further homogenization. It was expected that these different methods of preparation would alter the characteristics of the full-cream milk concentrate emulsion and that this would have consequences on the efficiency of fat encapsulation and the SEF in the final milk powder.

\section{MATERIALS AND METHODS}

\subsection{Manufacture of milk powders}

Full-cream milk was obtained from a local dairy company, Longwarry, Victoria on a number of occasions. A range of processing 


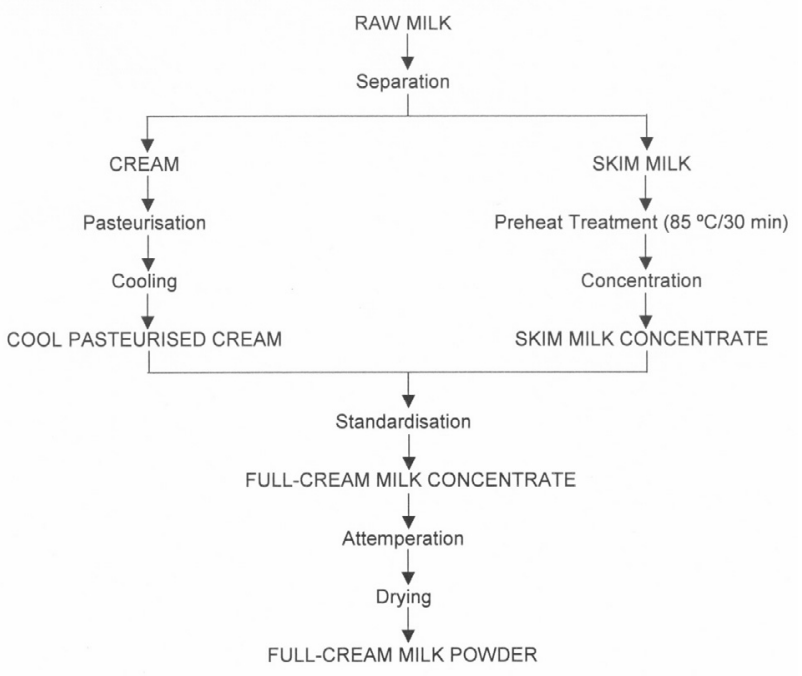

Figure 1. Alternative process combining cooled cream and skim concentrate and drying of unhomogenized full-cream concentrate. routes was used for the manufacture of FCMP with a target total fat content of $300 \mathrm{~g} \cdot \mathrm{kg}^{-1}$. A pilot scale tubular heating system was used for the preheating of both the cream and the milk ingredients. A Niro Production Minor (Niro A/S, Soborg, Denmark) was used for spray drying (Inlet temperature $160{ }^{\circ} \mathrm{C}$ and Outlet temperature $90^{\circ} \mathrm{C}$ ).

\subsubsection{Conventional processes for the preparation of full-cream milk concentrate}

Standardized milk was preheated $\left(85^{\circ} \mathrm{C}\right.$ for $30 \mathrm{~min}$ ), concentrated to $\sim 45 \%$ total solids and either fed straight into the dryer or homogenized at $175+35 \mathrm{~kg} \cdot \mathrm{cm}^{-2}$ at $50{ }^{\circ} \mathrm{C}$ prior to drying. Alternatively a preheated skim milk concentrate was mixed with a pasteurized separated cream and the reconstituted full-cream concentrate was homogenized prior to drying.

\subsubsection{Alternative process combining} cooled cream and skim concentrate and drying of unhomogenized full-cream concentrate

Whole milk was separated. The skim fraction was given a high-heat treatment $\left(85^{\circ} \mathrm{C}\right.$ for $30 \mathrm{~min}$ ) or low-heat treatment $\left(72{ }^{\circ} \mathrm{C}\right.$ for $\left.30 \mathrm{~s}\right)$ and concentrated. The cream was pasteurized $\left(72{ }^{\circ} \mathrm{C}\right.$ for $\left.30 \mathrm{~s}\right)$ and cooled to $5^{\circ} \mathrm{C}$. Skim milk concentrate was mixed with cooled cream and the mixture was fed into the dryer at various temperatures $\left(5-50{ }^{\circ} \mathrm{C}\right)$. In these experiments the reconstituted full-cream milk concentrate was not homogenized. The process is outlined in Figure 1.

\subsubsection{Alternative process combining homogenized cream and skim concentrate and drying of full-cream concentrate}

Whole milk was separated to obtain cream with the desired range of total solids and fat:milk solids non-fat (MSNF) ratios. The skim fraction was given a high-heat treatment $\left(85^{\circ} \mathrm{C}\right.$ for $\left.30 \mathrm{~min}\right)$ and concentrated. The cream was pasteurized $\left(72{ }^{\circ} \mathrm{C}\right.$ for $\left.30 \mathrm{~s}\right)$ and homogenized at $175+35 \mathrm{~kg} \cdot \mathrm{cm}^{-2}$ at $75^{\circ} \mathrm{C}$. The homogenized cream was mixed in with skim concentrate (without homogenization) and spray-dried. An outline of the process is given in Figure 2.

\subsection{Analyses}

\subsubsection{Analyses of creams and milk concentrates}

The total solids of the cream were obtained gravimetrically. Fat in cream was 


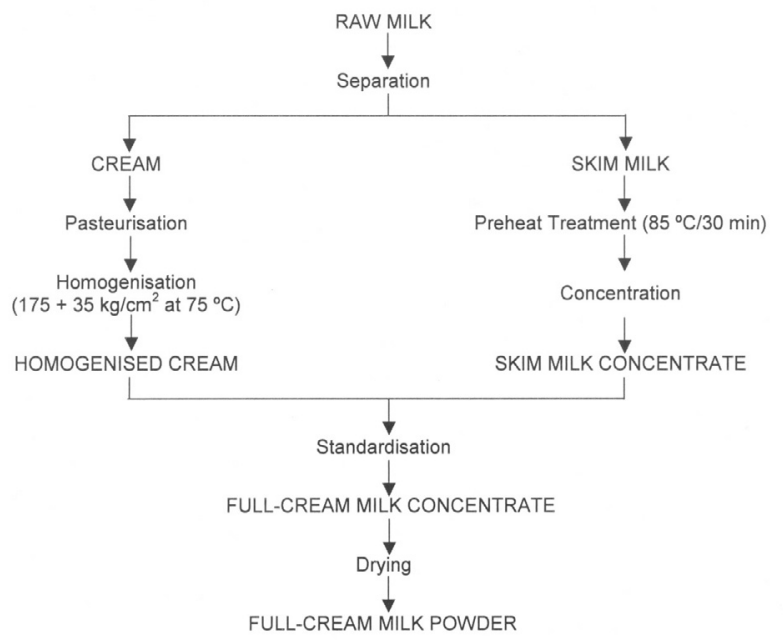

Figure 2. Alternative process combining homogenized cream and skim concentrate and drying of full-cream concentrate cream. determined by the Babcock method. The total solids of skim and full-cream milk concentrates were determined using a refractometer that had previously been calibrated by gravimetric analysis of concentrates.

\subsubsection{Analyses of powders}

The total fat of the powder was determined using a standard method [17]. The SEF of powders was determined according to that described in the NIRO method [21] except that the carbon tetrachloride was replaced with petroleum ether (b.p. 40$60^{\circ} \mathrm{C}$ ) with the result expressed as $\mathrm{g} \cdot \mathrm{kg}^{-1}$ of the total fat in the powder.

\section{RESULTS AND DISCUSSION}

\subsection{Conventional processes}

The use of the conventional processes using homogenized concentrates manufactured directly from concentration of standardized whole milk resulted in FCMP (300 $\mathrm{g} \cdot \mathrm{kg}^{-1}$ total fat) with $\sim 10 \mathrm{~g} \cdot \mathrm{kg}^{-1} \mathrm{SEF}$ (expressed as $\mathrm{g} \cdot \mathrm{kg}^{-1}$ of total fat in powder). When whole milk was separated and the skim and cream fractions were separately processed prior to mixing, homogenization and drying, powders with low SEF $\left(<40 \mathrm{~g} \cdot \mathrm{kg}^{-1}\right)$ were also obtained. These low values were as expected [12].

\subsection{Alternative process combining cooled cream and skim concentrate and drying of unhomogenized full-cream concentrate}

FCMP ( 300 $\mathrm{g} \cdot \mathrm{kg}^{-1}$ total fat) manufactured using the alternative process with cooled cream (Fig. 1) had higher SEF than powders produced by conventional processes. The SEF's in the powders made by the alternative process with cooled cream were between $130-360 \mathrm{~g} \cdot \mathrm{kg}^{-1}$ of total fat, depending on the parameters used during processing (Tabs. I-II).

Increasing the fat:MSNF ratio of cream that was mixed with the skim concentrate increased SEF when the feed temperature of the full-cream milk concentrate was constant (Fig. 3). This may be attributed to the destabilization of the separated cream emulsion with use of cream with high fat:MSNF ratios. At the higher ratios, there was possibly insufficient available surfaceactive material from the milk solid non-fat component for efficient encapsulation of the fat. Other work has shown that increasing the fat content of cream for combination 
Table I. Effect of gross cream composition on SEF of FCMP made by reconstitution of cooled cream and skim concentrate $\left(460-470 \mathrm{~g} \cdot \mathrm{kg}^{-1}\right.$ total solids) and fed to the dryer at various temperatures.

\begin{tabular}{|c|c|c|c|c|c|c|}
\hline $\begin{array}{l}\text { Cream total } \\
\text { solids } \\
\left(\mathrm{g} \cdot \mathrm{kg}^{-1}\right)\end{array}$ & $\begin{array}{l}\text { Cream fat: } \\
\text { MSNF } \\
\text { (ratio) }\end{array}$ & $\begin{array}{c}\text { Total solids of } \\
\text { skim concentrate } \\
\left(\mathrm{g} \cdot \mathrm{kg}^{-1}\right)\end{array}$ & $\begin{array}{l}\text { Total solids } \\
\text { of dryer feed } \\
\left(\mathrm{g} \cdot \mathrm{kg}^{-1}\right)\end{array}$ & $\begin{array}{l}\text { Total fat } \\
\text { of powder } \\
\left(\mathrm{g} \cdot \mathrm{kg}^{-1}\right)\end{array}$ & $\begin{array}{l}\text { Feed temperature } \\
\text { into dryer } \\
\left({ }^{\circ} \mathrm{C}\right)\end{array}$ & $\begin{array}{l}\text { SEF in powder } \\
\quad\left(\mathrm{g} \cdot \mathrm{kg}^{-1} \text { of }\right. \\
\text { total fat })\end{array}$ \\
\hline \multirow[t]{3}{*}{376} & 5.7 & 460 & 426 & 303 & 5 & 195 \\
\hline & & & & 305 & 24 & 132 \\
\hline & & & & 297 & 50 & 138 \\
\hline \multirow[t]{3}{*}{429} & 10.0 & 470 & 443 & 299 & 5 & 232 \\
\hline & & & & 294 & 24 & 222 \\
\hline & & & & 295 & 50 & 184 \\
\hline \multirow[t]{3}{*}{501} & 30.3 & 470 & 479 & 312 & 5 & 273 \\
\hline & & & & 316 & 24 & 248 \\
\hline & & & & 299 & 50 & 212 \\
\hline
\end{tabular}

Powders were made from the same batch of milk produced in June. Pooled SD of SEF $=2.0$.

Table II. Effect of total solids of skim milk concentrate on the SEF of FCMP ( $300 \mathrm{~g} \cdot \mathrm{kg}^{-1}$ fat) made from recombined cooled cream and skim concentrate fed into the dryer at $20{ }^{\circ} \mathrm{C}$.

\begin{tabular}{ccccc}
\hline \multicolumn{2}{c}{ Cream composition } & $\begin{array}{c}\text { Total solids of skim } \\
\text { concentrate } \\
\left(\mathrm{g} \cdot \mathrm{kg}^{-1}\right)\end{array}$ & $\begin{array}{c}\text { Total solids of feed } \\
\text { into dryer } \\
\left(\mathrm{g} \cdot \mathrm{kg}^{-1}\right)\end{array}$ & $\begin{array}{c}\text { SEF in powder } \\
\left(\mathrm{g} \cdot \mathrm{kg}^{-1} \text { of total fat }\right)\end{array}$ \\
\hline $\begin{array}{c}\text { Total solids } \\
\left.(\mathrm{kg})^{-1}\right)\end{array}$ & $\begin{array}{c}\text { Fat : MSNF } \\
(\text { ratio })\end{array}$ & 360 & 383 & 187 \\
468 & 8.75 & 420 & 435 & 247 \\
468 & 8.75 & 480 & 476 & 360 \\
\hline
\end{tabular}

Powders were made from the same batch of milk produced in January.

Pooled SD of SEF $=2.0$.

with skim milk solids to produce creams with $\sim 400 \mathrm{~g} \cdot \mathrm{kg}^{-1}$ total fat increases the particle size of the final cream emulsions [11].

The observation that higher SEF content in powder was generally obtained when the feed temperature of the full-cream concentrate was decreased (Tab. I, Fig. 3) may be related to the increase in the solid fat content with decrease in temperature due to increased damage of the milk fat globule membrane (MFGM). Miller and Puhan [15] suggest that cooling of milk has a greater effect on lipolysis than stirring. As milks with undamaged milk fat globule membranes are not susceptible to lipolysis, the results of Miller and Puhan [15] imply that the milkfat globule is more susceptible to damage when milk is cooled. This is in line with our observations as more SEF in powders is expected when the concentrate is cooled to $5^{\circ} \mathrm{C}$ and the susceptibility of the milkfat globule membrane to damage is increased.

SEF content in powder increased with an increase in the total solids of the skim milk concentrate used for standardization of 


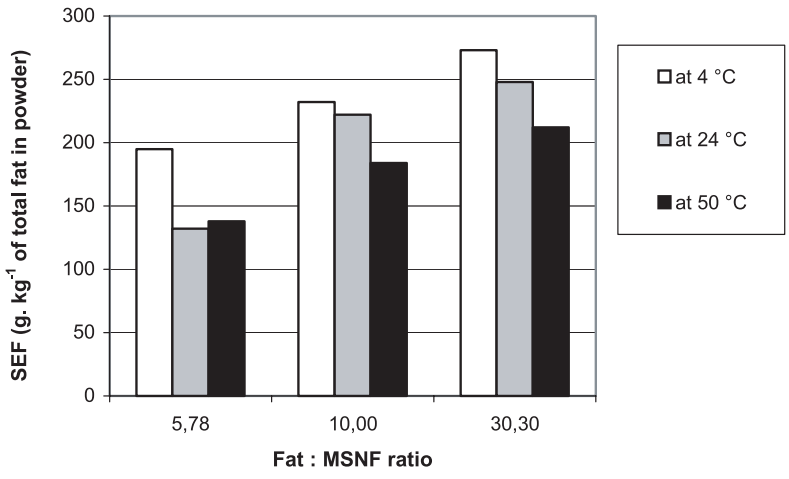

Figure 3. Alternative process combining cooled cream and skim concentrate and drying of unhomogenized full-cream concentrate at various temperatures. cream to produce a reconstituted full-cream milk concentrate that was subsequently dried (Tab. II). A possible contributory factor to the higher level of SEF in powders made from higher solids concentrates is the increased aggregation of protein in skim concentrates with higher total solids. In aggregated states, proteins have lower emulsifying capacity.

\subsection{Alternative process combining homogenized cream and skim concentrate and drying of full-cream concentrate}

High temperature and high pressure homogenization of separated cream prior to recombination of the cream with skim milk concentrate and drying yielded FCMP $\left(\sim 300 \mathrm{~g} \cdot \mathrm{kg}^{-1}\right.$ total fat) with high levels of SEF $\left(\sim 350-420 \mathrm{~g} \cdot \mathrm{kg}^{-1}\right.$ of total fat in powder) (Tab. III). Alteration of the fat:MSNF ratio of the cream or change in the temperature of the feed into the dryer did not have a marked influence on the SEF in the resultant powder. This suggests that the process of homogenization of the cream prior to mixing it back with the skim concentrate was the major factor influencing SEF and that compositional factors (i.e. the fat:MSNF ratio) and the temperature of the feed into the dryer had minimal effects compared to the effects of destabilization of the cream during homogenization.

The conventional use of homogenization is to prevent cream separation in whole milk. However, it is possible to destabilize creams under some conditions where the new fat surface area created by the homogenization process cannot be adequately stabilized by the available surface-active material. Homogenization of high fat dairy premixes for the production of high fat powders at too high a temperature (70$75^{\circ} \mathrm{C}$ ) and pressure (150-200 $\mathrm{kg} \cdot \mathrm{cm}^{-2}$ ) causes difficulties during drying [3]. The observations of these authors may be due to the destabilization of the creams with the severe homogenization treatment, which resulted in powders with high SEF.

Limited work has shown that differences in SEF content of powders were obtained when powders were prepared in a similar way from cream and skim milk concentrates with matched gross composition manufactured from different batches of milk (Tab. III, Series 2). The reasons for the differences observed were not investigated. Possible contributory factors are the changes in minor components in the milk such as minerals (which can mediate a change in the emulsification characteristics of the milk proteins by influencing their state of aggregation) or the level of small molecular weight surfactants such as mono- and di-glycerides or hydrolyzed protein (which have the capacity to affect the emulsion stability).

\section{CONCLUSION}

The SEF content of milk powders is affected by the stability of the emulsions used for preparation of FCMP. The nature of the milk fat globule membrane of the 
Table III. SEF in FCMP ( 300 g. $\mathrm{kg}^{-1}$ fat $)$ made by combining homogenized cream with skim milk concentrate.

\begin{tabular}{|c|c|c|c|c|c|c|c|}
\hline Trial & $\begin{array}{l}\text { Total solids } \\
\text { of skim } \\
\text { concentrate } \\
\left(\mathrm{g} \cdot \mathrm{kg}^{-1}\right)\end{array}$ & $\begin{array}{l}\text { Total solids } \\
\text { of cream } \\
\left(\mathrm{g} \cdot \mathrm{kg}^{-1}\right)\end{array}$ & $\begin{array}{l}\text { Cream } \\
\text { fat: } \\
\text { MSNF } \\
\text { (ratio) }\end{array}$ & $\begin{array}{c}\text { Total solids } \\
\text { of feed into } \\
\text { dryer } \\
\left(\mathrm{g} \cdot \mathrm{kg}^{-1}\right)\end{array}$ & $\begin{array}{c}\text { Temperature } \\
\text { of feed into } \\
\text { dryer } \\
\left({ }^{\circ} \mathrm{C}\right)\end{array}$ & $\begin{array}{l}\text { Fat content } \\
\text { of powder } \\
\left(\mathrm{g} \cdot \mathrm{kg}^{-1}\right)\end{array}$ & $\begin{array}{l}\text { SEF in } \\
\text { powder } \\
\left(\mathrm{g} \cdot \mathrm{kg}^{-1} \text { of }\right. \\
\text { total fat })\end{array}$ \\
\hline \multirow[t]{6}{*}{ Series 1\# } & 470 & 440 & 9.1 & 460 & 5 & 294 & 355 \\
\hline & & & & & 40 & 305 & 378 \\
\hline & & & & & 60 & 311 & 350 \\
\hline & & 490 & 14.8 & 476 & 5 & 308 & 395 \\
\hline & & & & & 40 & 301 & 332 \\
\hline & & & & & 60 & 303 & 351 \\
\hline \multirow[t]{2}{*}{ Series $2^{*}$} & 420 & 480 & 16.1 & 437 & 40 & 295 & 361 \\
\hline & 430 & 450 & 14 & 436 & 40 & 293 & 417 \\
\hline
\end{tabular}

\# For series 1 powders were made from the same batch of milk produced in May.

* For series 2 powders were made from different batches of milk produced in June.

Pooled SD of SEF $=2.0$.

cream is an important determinant of the SEF in the resultant powder. Factors, which destabilise the fat globules in the cream or the reconstituted full-cream concentrate, lead to high SEF in powders. This work has suggested that simple processing interventions, such as separation, cooling and homogenization of cream, and alteration of processing steps within milk powder processing can lead to increased SEF in powder.

Acknowledgements: This work was supported by the CSIRO Division of Food Science and Technology and the Dairy Research and Development Corporation. The assistance of A. Lawrence and $\mathrm{J}$. Underwood in manufacture and analyses of powders is gratefully acknowledged.

\section{REFERENCES}

[1] Aguilar C.A., Ziegler G.R., Physical and microscopic characterization of dry whole milk with altered lactose content. 2. Effect of lactose crystallization, J. Dairy Sci. 77 (1994) 1198-1204.

[2] Augustin M.A., Dairy ingredients in chocolate - chemistry and ingredient interactions, Food Aust. 53 (2001) 389-391.
[3] Barbier J.-P., Feugnet J.-P., Process for manufacturing a milk powder with high content in, mainly butter, food fat, Patent Application FR 2134573, 1971.

[4] Bohren H.U., Kuypers T.W., Meister N., Product and process for production of a milk powder, Patent Application US 4871573, 1989.

[5] Buma T.J., Free-fat in spray-dried whole milk. 3. Particle size. Its estimation, influence of processing parameters and its relation to free-fat content, Neth. Milk Dairy J. 25 (1971) 53-72.

[6] Buma T.J., Free-fat in spray-dried whole milk. 8. The relation between free-fat content and the particle porosity of spray-dried milk, Neth. Milk Dairy J. 25 (1971) 123-140.

[7] Buma T.J., Free-fat in spray-dried whole milk. 10. A final report with a physical model for free-fat in spray-dried milk, Neth. Milk Dairy J. 25 (1971) 159-174.

[8] De Vilder J., Martens R., Naudts M., Influence of process variables on some whole milk powder characteristics, Milchwissenschaft 31 (1976) 396-401.

[9] De Vilder J., Martens R., Naudts M., The influence of the dry matter content, the homogenization and the heating of concentrate on physical characteristics of whole milk powder, Milchwissenschaft 34 (1979) 78-84. 
[10] Hansen S.O., Hansen P.S., Spray-dried whole milk powder for the manufacture of chocolate, Scand. Dairy Inf. 4 (1990) 79-82.

[11] Hillbrick G., Shen Z., Ainsworth S., Piovesan D., Augustin M.A., Influence of cream separation conditions on the physical properties of cream, Aust. J. Dairy Technol. 55 (2000) 84.

[12] Hols G., Van Mil P.J.J.M., An alternative process for the manufacture of whole milk powder, J. Soc. Dairy Technol. 44 (1991) 49-52.

[13] Kelly J., Kelly P.M., Harrington D., Influence of processing variables on the physico-chemical properties of spray-dried fat-based milk powders, Lait 82 (2002) 401-412.

[14] Knipschildt M.E., Recent developments in spray drying of milk, in: MacCarthy D. (Ed.), Concentration and Drying of Foods, Elsevier Applied Sciences Publishers, Essex, England, 1986, pp. 221-270.

[15] Miller B., Puhan Z., Fat damage during milking and milk handling, Schweiz. Milchwirtsch. Forsch. 15 (1986) 69-76.
[16] Reimerdes E.H., Mehrens H.A., Milk, in: Beckett S.T. (Ed.), Industrial Chocolate Manufacture and Use, 2nd edn., Blackie Academic \& Professional, Glasgow, Scotland, 1993, pp. 43-54.

[17] Standards Association of Australia, Methods for analysis of dried milk and whey, Standard SAA1629: SAA, Melbourne, Australia, 1974.

[18] Tamsma A., Edmondson L.F., Vettel H.E., Free-fat in foam dried whole milk, J. Dairy Sci. 42 (1959) 240-250.

[19] Twomey M., Keogh M.K., O’Kennedy B.T., Auty M., Mulvihill D.M., Effect of milk composition on selected properties of spray-dried high-fat and skim milk powders, Ir. J. Agric. Food Res. 39 (2000) 79-94.

[20] Verhey J.P.G., Physical properties of dried milk in relation to chocolate manufacture, Neth. Milk Dairy J. 40 (1986) 261-268.

[21] Westergaard V., Milk Powder Technology: Evaporation and Spray Drying. NIRO, Copenhagen, Denmark, 1994, pp.91-92. 